\title{
A Mediating Role of Knowledge Management System in the Relationship between Information Technology Infrastructure and E-Government Performance
}

\author{
Nazanin Mansouri \\ HELP University \\ Kuala Lumpur, Malaysia
}

\begin{abstract}
This paper as a qualitative paper attempts to review extant research in term of e-government performance, knowledge management system, and information technology infrastructure. Nowadays, various countries are trying to improve their performance by using information technology. In this regard, knowledge management can be considered an influential factor which plays a vital role in the relationship between IT infrastructure and e-government performance. In the sequel, this paper proposes a framework which can be applied for future study.
\end{abstract}

Keywords: Knowledge Management System, Information Technology Infrastructure, E-government, Performance.

\section{INTRODUCTION}

Through growth and development of technology these days, not only the companies but also governments also attempt to use technology in order to improve their performance. Egovernment (Electronic Government) includes some digital interactions between citizens and the government known as $\mathrm{G} 2 \mathrm{C}$, business/commerce and government (G2B), employees and government $(\mathrm{G} 2 \mathrm{E})$, between government /agencies and government $(\mathrm{G} 2 \mathrm{G})$ and also government interaction with citizens $(\mathrm{C} 2 \mathrm{G})$. Generally delivery models of e-government could be summed up briefly as the (Turban et al., 2009; Bonson et al., 2012):

- $\mathrm{G} 2 \mathrm{C}$ (government to citizens)

- G2B (government to businesses)

- G2E (government to employees)

- $\mathrm{G} 2 \mathrm{G}$ (government to governments)

- $\quad \mathrm{C} 2 \mathrm{G}$ (citizens to governments)

It is clear that for improving the e-government performance there should be some preparations. One of the critical topics in e-government is IT infrastructure (Welch et al., 2005; Heeks and Bailur, 2007). This infrastructure should be developed in a way that improve and increase the egovernment performance. Most of developing countries are attempting to improve this infrastructure in their egovernments. It is clear that according to different dimensions of IT, there is a need to understand its weaknesses (Ramirez et al., 2010; Turban et al., 2008). This will help to improve IT infrastructure and the performance of e-government will be increased.

One of the important topics in e-government is decision making. Usually important decision makings require having enough and categorized information. This information sometimes is explicit in minds of the experts and sometimes is written and documented. Thus, related to using the existed (DSS) decision support system in e-government, there should be knowledge management system. On the other hand, knowledge management system in e-government is not well recognized. This can be considered as the gap of previous studies. The conducted researches by Yang et al. (2012) demonstrated that IT application (both advanced and basic tools) can impact project performance and knowledge management system (KM) at the same time. In addition, Nonaka and Takeuchi $(1992,2007)$ in their SECI model explained that knowledge sharing as one of the dimensions of $\mathrm{KM}$ system can lead to knowledge creation. Hence, the existed knowledge in background of e-government related to improving the performance can be managed. Managing this knowledge will facilitate the decision making because decision makers can concentrate on different aspects more appropriately.

As it was mentioned before, for managing the knowledge there should be IT infrastructure. Hence this study aims to justify the relationship between IT infrastructure, KM system and thereby e-government performance.

\section{LITERATURE REVIEW}

\subsection{E-government}

The strategy of e-government is one of the critical factors for modernization of public sector by means of developing and understanding organizational structure, interaction approaches with business and citizens and also minimizing costs and layers of process regarding organizational business. It brings a wide range of information for businesses and citizens via internet. By the way, e-government's role is not just bringing services and information to the citizens that can be offered by commercial companies. The e-government can develop helpful strategic connections among departments with public sector firms and also create a communication between different levels of the government for example local and central city.

This communication and connection will improve the cooperation among them via facilitating the implementation and provision of government transactions, strategies and also policies and in addition better running and using the governmental information, resources and processes (Cabinet Office, 2000; Heeks, 2001). Also the government can transfer the funds electronically into the other agencies of the government and bring information for public staffs by means 
of internet or intranet. Cabinet Office (2000) and Tyndale (2002) stated that e-government advanced the communications among various parts inside the government and as a result individuals will not need to repeatedly ask about similar information from various providers of the service.

By means of a web portal which is integrated, the businesses and citizens can do the transactions with agencies in government with no need to visit many different departments/ministries in different physical places. Also, strategy of e-government helps the public sector or firms to directly interact and operate better with the businesses and there will be no importance about their locations. This will have digitizing procurement services for the businesses for improving their service quality, cost effectiveness as well as convenience (Heeks, 2001; McClure, 2000).

Moreover, government officials and leaders are highly know about the e-government potential for promoting the performance of governmental firms and bring some benefits for business partners and the citizens. By the way, egovernment adoption is not totally straightforward and could not be accomplished in a short time and instead it needs an architecture integrative framework method to put the government services and information online. This can be a reason that why a lot of governmental firms still are in beginning stages of adopting e-government. The other critical reason regarding this delay is that e-government needs remarkable changes in organizational infrastructure that as a result can increase resistance. So these reasons make the scholar to creat an architecture integrative framework for the adoption of e-government.

\subsection{Knowledge Management}

In an uncertain economy, the knowledge is the source that can lead the company to CA (Nonaka and Von Krogh, 2009). In this regard, a company should increase the knowledge inside the organization for being successful (Nonaka and Toyama, 2007).

Based on statements of Brian Newman (1995) knowledge management $(\mathrm{KM})$ is the process of gathering, creating, disseminating and utilizing the knowledge. $\mathrm{KM}$ has been found and understood since so many years ago. These days, different scholars have knowledge about using it including philosophers, scribes, teachers and priests (Cochrane, Webb \& Newman, 1995)

The question here is that if $\mathrm{KM}$ has been utilized since many years ago what is the role of $\mathrm{KM}$ in case of information these days? The mentioned progresses are existed and they have a deep impact on decision making and action taking of individuals. They both probably are made in different types of knowledge. As Thomas Bertels (1998) noted, managing the renewal system knowledge of organizations is knowledge management or KM.

I. Providing supportive structure for the organization

II. Putting IT-Tools

III. Facilitation employees of the organization

Thomas Bertels is a practical person, highly focused on practical aspects of knowledge in case of having effective enhancements.

Knowledge management has so many different definitions and those published supporting terms by different experts and authors. Maarten Sierhuis is known as a person who defined the KM as following (Alavi and Leidner, 2001).

The capability of managing knowledge is called $\mathrm{KM}$ or known as knowledge management. Information management is remarkably common and familiar. It is a term that people need sources for comprehension of the information as well as having the ability to use them within the organizations (Scalea, 2008). In addition, information planning and information analyses concepts are initiated from knowledge management as well. currently the organizations are looking for knowledge sources so they will need many new ideas and methods for organizational management. in order to do different techniques such as knowledge technology and knowledge planning, different methods should be developed for examining the organizational knowledge sources (Wong\&Aspinwall, 2005).

Based on statements of Gregory Wenig, the KM has been provided firm many different actions which the organization achieves from their experiences or others and in addition they can fulfill the mission of the company by logical and rational knowledge observation. These actions can be helpful for developing organizational structure, technology and strategies based on cognitive approaches for improving the existed knowledge yield and providing new knowledge. The necessary attempt is that the surging of cognitive system (computer, organization, human or may be the combination of them all) for using, maintaining and achieving knowledge for realizing how to find solution for issues and making the best decisions possible (Firestone, 2001).

\subsection{Related Research on Knowledge Management and Performance}

By considering the fact that e-government performance is close to project performance there are many different researches that show the important role of KM. Generally, many experts have stated that information technology provides significant benefits for KM. In addition, it was revealed that $\mathrm{KM}$ has a critical key role for projects and performance of the organizations. The beneficial management of built facility requires influential $\mathrm{KM}$ in order to support it properly (Rooke et al., 2010).

In previous researches, knowledge management was known as relevant to results of critical performance (Egbu, 1999, Liu, 2004, Carrillo, 2006, Adenfelt, 2010). In addition, in 1999, Carayannis examined the role of $\mathrm{KM}$ relevant to growing synergistic symbiosis between IT and organizational cognition. The previous researches demonstrated that knowledge management has a mediating role regarding the existed relationship between information technology and performance results (Chen \& Liang, 2003). Then, Yang et al. (2012) expanded the previous studies through adding the relationships among IT application, KM and project success for capital faculty.

Moreover, there are several studies (e.g. Gudi and BecerraFernandez, 2006) about the existed relationship among project performance, KM, project risk, team adoption and project success (Fig.1). 


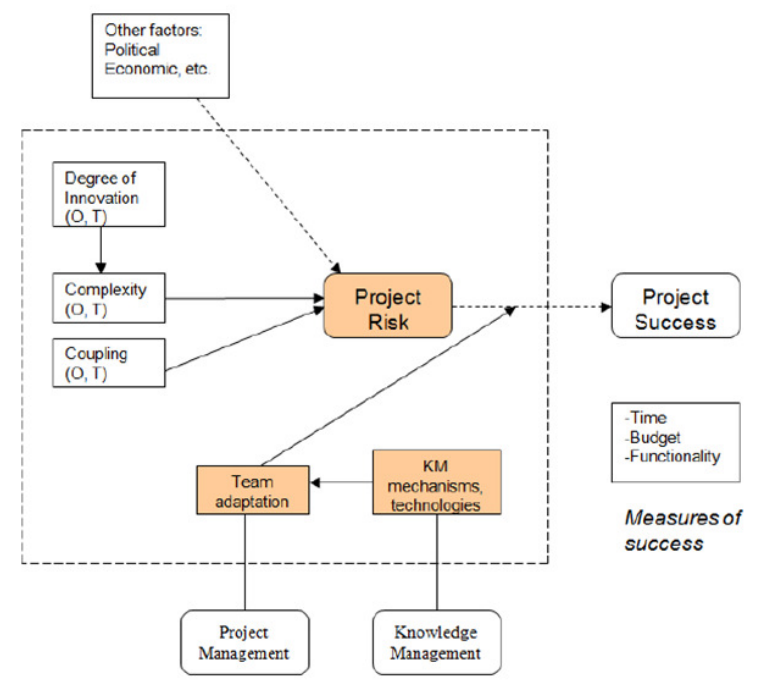

Figure 1: Gudi and Becerra- Fernandez (2006)

Ismail et al. in 2009 presented an integrated model which connects sharing knowledge to project management in order to increase success of a project. In this framework, organizational and individual motivation elements have critical role for improving knowledge sharing and as a result success of the project (Fig.2).

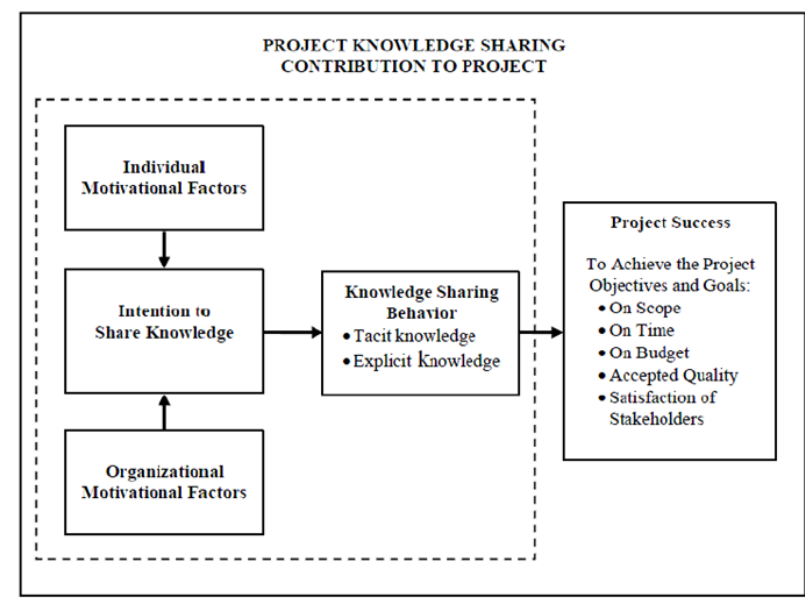

Figure 2: Ismail et al. (2009)

According to Figure 2 above, organizational and individual factors enhance the knowledge sharing intention. In next level intention can increase behavior of knowledge sharing which in turn increases project success.

Yeong and Lim (2011) suggested an integrity framework which connects project management to knowledge management in order to increase project success. In this framework both organizational and individual motivation elements have critical role for improving the knowledge sharing which leads to more project success (Fig.3).

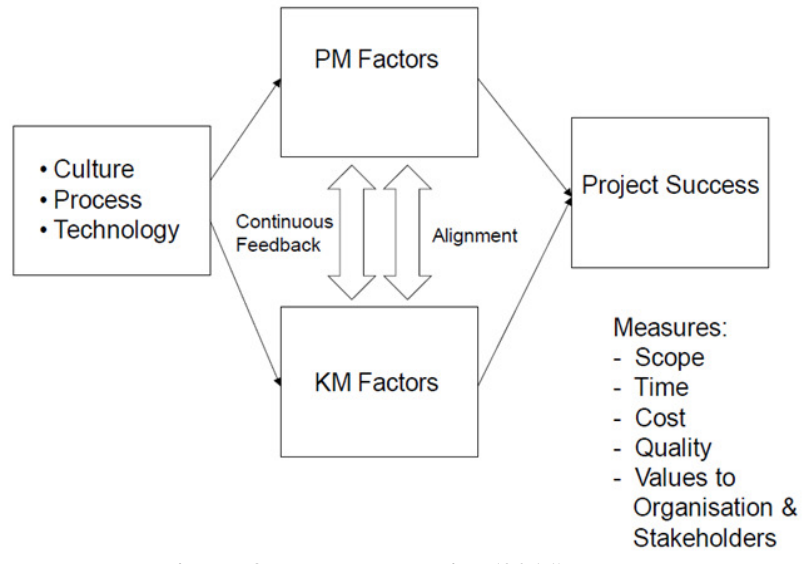

Figure 3: Yeong and Lim (2011)

\section{PROPOSED FRAMEWORK AND FUTURE STUDY}

As it discussed above, there are enough evidences to show that information technology can affect knowledge management and e-government performance. In this regard, figure 4 shows this relationship based on intervening role of KMS.

Future study at first used qualitative approach for understanding the information technology infrastructures' weakness. This approach will contribute to define proper IT infrastructures. In the next step, future study should attempt to utilize questionnaire for testing the below framework.

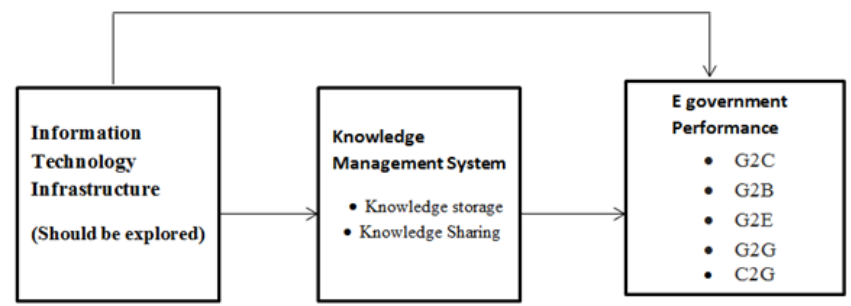

Figure 5: Proposed Framework

Because of the fact that the emphasis of e-government is on G2C, G2B, G2E, G2G, and C2G so it is important to design the most appropriate questionnaire after interviewing with the experts.

\section{REFERENCES}

[1] Abduh M., Skibniewski M., J. (2004). Electronic networking technologies in construction, Journal of Construction Research 5 (1), 17-42.

[2] Adenfelt M. (2010). Exploring the performance of transnational projects: sharedknowledge, coordination and communication, International Journal of ProjectManagement 28 (6), 529-538.

[3] Adriaanse A., Voordijk H., Dewulf G. (2010). Adoption and use of interorganizational ICT in a construction project, Journal of Construction Engineering and Management136 (9) (2010) 1003-1014.

[4] Alavi, M., \&Leidner, D. E. (2001). Review: Knowledge management and knowledge management systems: Conceptual foundations and research issues. MIS quarterly, 107-136. 
[5] Bertels, T., \& Savage, C. M. (1998). Tough questions on knowledge management. Knowing in firms, 7-25.

[6] Bertels, T., \& Savage, C. M. (1999). A research agenda for the knowledge era: The tough questions. Knowledge and Process Management, 6(4), 205-212.

[7] Bonsón, E., Torres, L., Royo, S., \& Flores, F. (2012). Local e-government 2.0: Social media and corporate transparency in municipalities. Government Information Quarterly, 29(2), 123-132.

[8] Cabinet Office (2000). Electronic Government Services for the 21st Century, Cabinet Office, London.

[9] Carrillo P. (2004). Managing knowledge: lessons from the oil and gas sector, ConstructionManagement and Economics 22 (6), 31-42.

[10] Carayannis E.G. (1999). Fostering synergies between information technology andmanagerial and organizational cognition: the role of knowledge management, Technovation 19 (4), 219-231.

[11] Ding Z., Ng F., Cai O. (2007), Personal constructs affecting interpersonal trust and willingness to share knowledge between architects in project design teams,Construction Management and Economics 25 (9), 937-950.

[12]Egbu C. O. (1999), Skills, knowledge and competencies for managing constructionrefurbishment works, Construction Management and Economics 17 (1), 29-43.

[13] Glass J. (2005). A best practice process model for hybrid concrete construction,Construction Management and Economics 23 (2), 169-184.

[14] Goodrum P.M., Gangwar M. (2004). The relationship between changes in equipmenttechnology and wages in the US construction industry, Construction Managementand Economics 22 (3), 291-301.

[15] Grilo A., Jardim-Goncalves R. (2010).Value proposition on interoperability of BIM andcollaborative working environments, Automation in Construction 19 (5), 522530 .

[16] Gudi, A., \& Becerra-Fernandez, I. (2006, March).Role of knowledge management in project management of complex systems organizations. In NASA Knowledge Management and Successful Mission Operations Conference.

[17] Heeks, R. (2001),Understanding E-Governance for Development, Institute for Development Policy and Management, Manchester.

[18] Heeks, R., \&Bailur, S. (2007). Analyzing E-Government Research: Perspectives, Philosophies, Theories, Methods, And Practice. Government Information Quarterly, 24(2), 243-265.

[19] Isikdag U., Underwood J. (2010). Two design patterns for facilitating Building Information Model-based synchronous collaboration, Automation in Construction 19 (5), 544-553.
[20] Liu P. L., Chen W. C., Tsai C. H. (2004). An empirical study on the correlation between knowledge management capability and competitiveness in Taiwan's industries, Technovation 24 (12), 971-977.

[21] McClure, D. (2000), "Electronic government: federal initiatives are evolving rapidly but they face significant challenges", Accounting and Information Management Division, available www.gao.gov/new.items/a200179t.pdf.

[22] Mitropoulos P., Tatum C. B., Forces driving adoption of new information technologies, Journal of Construction Engineering and Management 126 (5)(2000) 340-348.

[23] Nonaka, I., \& Von Krogh, G. (2009). Perspective-tacit knowledge and knowledge conversion: Controversy and advancement in organizational knowledge creation theory. Organization science, 20(3), 635-652.

[24] Nonaka, I., \& Toyama, R. (2007). Strategic management as distributed practical wisdom (phronesis). Industrial and Corporate Change, 16(3), 371-394.

[25] Peansupap V., Walker D. (2005). Factors affecting ICT diffusion: a case study of three largeAustralian construction contractors, Engineering, Construction and ArchitecturalManagement 12 (1), 21-37.

[26] Turban, E., Lee, J. K., King, D., Liang, T. P., \& Turban, D. (2009). Electronic commerce 2010.Prentice Hall Press.

[27] Ramirez, R., Melville, N., \& Lawler, E. (2010). Information technology infrastructure, organizational process redesign, and business value: an empirical analysis. Decision Support Systems, 49(4), 417-429.

[28] Rooke C.N., Rooke J.A., Koskela L., Tzortzopoulos P. (2010). Using the physical properties Of artefacts to manage through-life knowledge flows in the built environment: an initial exploration, Construction Management and Economics 28 (6) (2010)601-613.

[29] Sage D.J., Dainty A.R.J., Brookes N.J. (2010). Who reads the project file? Exploring thepower effects of knowledge tools in construction project management, Construction Management and Economics 28 (6), 629639.

[30] Sexton M., Barrett P. (2004), The role of technology transfer in innovation within smallconstruction firms, Engineering, Construction and Architectural Management 11(5), 342-348.

[31] Scalea, (2008). Optimal timing of fracture fixation: have we learned anything in the past 20 years?. Journal of Trauma-Injury, Infection, and Critical Care, 65(2), 253260. 
International Journal of Science and Engineering Applications

Volume 4 Issue 5,2015, ISSN 2319-7560 (Online)

[32] Styhre A., Gluch P. (2010), Managing knowledge in platforms: boundary objects andstocks and flows of knowledge, Construction Management and Economics 28 (6), 589-599.

[33] Tse R.Y., Choy L. (2005). Is IT training in construction industry useful? Journal ofConstruction Research 6 (1), $1-13$.

[34] Turban, E., Leidner, D., Mclean, E., \&Wetherbe, J. (2008). Information Technology For Management, (With Cd). John Wiley \& Sons.

[35] Tyndale, P. (2002), “Will e-government succeed?”, paper presented at 2nd European Conference on EGovernment, St Catherine's College, Oxford, pp. 429-38.

[36] Welch, E. W., Hinnant, C. C., \& Moon, M. J. (2005). Linking Citizen Satisfaction With E-Government And Trust In Government. Journal Of Public Administration Research And Theory, 15(3), 371-391.
[37] Wong, K. Y., \&Aspinwall, E. (2005).An empirical study of the important factors for knowledge-management adoption in the SME sector.Journal of knowledge management, 9(3), 64-82.

[38] Yang, L. R., Chen, J. H., \& Wang, H. W. (2012).Assessing impacts of information technology on project success through knowledge management practice. Automation in Construction, 22, 182-191.

[39] Yeong, A., \& Lim, T. T. (2010).Integrating knowledge management with project management for project success. J Proj Program Portfolio Manage, 1(2), 8-19. 